\title{
Cultivar Origin and Admixture Detection in Turkish Olive Oils by SNP-Based CAPS Assays
}

\author{
Ali Tevfik Uncu, Anne Frary, and Sami Doganlar* \\ Department of Molecular Biology \& Genetics, Izmir Institute of Technology, Urla, Izmir 35430, Turkey
}

\begin{abstract}
The aim of this study was to establish a DNA-based identification key to ascertain the cultivar origin of Turkish monovarietal olive oils. To reach this aim, we sequenced short fragments from five olive genes for SNP (single nucleotide polymorphism) identification and developed CAPS (cleaved amplified polymorphic DNA) assays for SNPs that alter restriction enzyme recognition motifs. When applied on the oils of 17 olive cultivars, a maximum of five CAPS assays were necessary to discriminate the varietal origin of the samples. We also tested the efficiency and limit of our approach for detecting olive oil admixtures. As a result of the analysis, we were able to detect admixing down to a limit of $20 \%$. The SNP-based CAPS assays developed in this work can be used for testing and verification of the authenticity of Turkish monovarietal olive oils, for olive tree certification, and in germplasm characterization and preservation studies.
\end{abstract}

KEYWORDS: food authentication, molecular markers, monovarietal olive oil, Olea europaea L., traceability

\section{INTRODUCTION}

Olive oil has been a characteristic component of the Mediterranean diet and culture since ancient times and has significant economic importance in the region. ${ }^{1,2}$ Virgin olive oil, produced from olive fruits by only mechanical processing, is among the most valuable agro-food products. ${ }^{3}$ Due to its protective effects against cancer and coronary heart disease, ${ }^{4}$ olive oil is a major contributor to the reputation of the Mediterranean diet. The health promoting properties of olive oil are attributed to its high oleic acid, squalene, and phenolic antioxidant contents. ${ }^{4}$ In parallel with increased recognition of its health benefits, olive oil consumption is expanding throughout the world, including the Americas, China, and Australia. ${ }^{5}$ While this expansion increases the importance of olive oil in the agricultural economies of olive producing countries, it also highlights the necessity for certifying the authenticity of products labeled as "virgin olive oil". Adulteration of virgin olive oil not only involves mixing with seed oils or lower grade refined olive oil, but also refers to fraudulent mislabeling of cultivar origin. ${ }^{6}$ Because the quality characteristics of virgin olive oils such as color and taste are mainly defined by the olive cultivar from which the oil is extracted, there is consumer preference for oils of certain cultivars, and such products are sold at a price premium. ${ }^{7}$ European Council Regulation (EC) No 510/2006 of 20 March 2006 on the protection of geographical indications and designations of origin for agricultural products and foodstuffs, defines the labels PDO (protected designation of origin) and PGI (protected geographical indication). Olive oils awarded these labels command even higher market prices. Therefore, reliable methods to authenticate premium monovarietal olive oils are required to protect the consumer from fraud and prevent unfair competition in the olive oil market.

Conventional olive oil authenticity tests involve the use of analytical chemistry methods to measure the composition of metabolites such as fatty acids, triacyl-glycerols, and unsaponifiable matter. ${ }^{8}$ However, these methods are not as successful in identifying the varietal composition of an olive oil sample as they are in identifying admixtures with seed oils. ${ }^{6}$ This is mainly due to the fact that metabolite composition of a given variety's oil is highly affected by environmental conditions, ${ }^{9-12}$ as well as postharvest and postproduction treatments. ${ }^{13}$

A promising approach for eliminating environmentally induced compositional variation is the recently emerging concept of food genomics. ${ }^{3}$ Because it is not subject to environmental influence, the residual DNA in a food sample directly represents the species/variety from which the food is produced. Therefore, once DNA is successfully recovered from the food matrix, PCR-based techniques allow amplification of it to sufficient quantities for further analyses. Significant success was achieved in detecting adulterants and contaminants in food products at the species level using approaches that involve PCR amplification of a discriminatory target, coupled with a sensitive mutation detection method. For example, hazelnut contamination in processed food products was successfully detected by analyzing chloroplastic PCR targets with a HRM (high resolution melting) approach. ${ }^{14}$ In other work, detection of canola oil adulteration in olive oil down to a limit of $1 \%$ was achieved using this technique. ${ }^{15}$

During the past decade, several authors reported the use of DNA markers for the authentication of the varietal origin of olive oils. The most frequently used DNA markers in such work are SSRs (simple sequence repeats) $)^{2,5,16-20}$ because degraded DNA recovered from an oil sample still allows the amplification of short PCR targets sufficient for SSR analysis. ${ }^{21}$ However, the most recent generation of DNA markers, SNPs (single nucleotide polymorphisms), can be used for genotyping with even shorter DNA fragments than SSRs. In addition, the high frequency of SNPs in both coding and noncoding parts of the

Received: October 27, 2014

Revised: February 11, 2015

Accepted: February 12, 2015

Published: February 12, 2015 
genome allows the differentiation of even closely related genotypes. ${ }^{6,22}$ For example, Ganopoulos et al. ${ }^{23}$ were successful in discriminating 21 Greek sweet cherry cultivars by genotyping nine genic SNP loci. Moreover, a sufficient number of SNPs for varietal origin detection can be identified by analyzing relatively short DNA sequences. Reale et $\mathrm{al}^{24}$ did the first work describing SNP marker development for olive cultivar identification and identified 22 SNPs with only 3440 bp (base pair) of olive genic sequence. Thus, they observed a high frequency of SNP occurrence (1 SNP per $156 \mathrm{bp}$ ). Using a total of 11 markers, 8 of which were SNP derived, Reale et al. ${ }^{24}$ discriminated 47 olive accessions. Following Reale et al., ${ }^{24}$ Consolandi et al. ${ }^{25}$ used 17 SNP loci to differentiate 49 olive varieties that are commonly cultivated in the Mediterranean region and developed a SNP-based ligation detection assay for varietal origin detection. The efficiency of the SNP-based ligation detection assay was displayed on eight monovarietal olive oils from Italy, Spain, France, and Portugal. ${ }^{1}$

Restriction profile-based genotyping, either referred to as CAPS or PCR-RFLP (PCR-restriction fragment length polymorphism), has been successfully used in a number of DNAbased food authentication studies. Dooley et al. ${ }^{26}$ were able to discriminate ten white fish species by using three PCR-RFLP assays that target a $464 \mathrm{bp}$ region of the Cytochrome $b$ gene. In addition, the reproducibility of the assays was displayed by an interlaboratory study that involves five different food control laboratories in the United Kingdom. Spaniolas et al. ${ }^{27}$ described a single SNP-based PCR-RFLP assay that allows the discrimination of Arabica and Robusta coffee samples. Bazakos et $\mathrm{al}^{21}$ were first to display the effectiveness of a PCR-RFLP (restriction fragment length polymorphism) approach to identify the varietal origin of olive oils based on their SNP alleles. The authors were able to discriminate eight olive varieties using five SNPs and showed the usefulness of this approach on five Greek monovarietal olive oils.

Turkey is among the world's leading olive producers and ranks fourth with 1676000 tonnes $(\mathrm{t})$ of total production, following Spain $(7875000 \mathrm{t})$, Italy $(3022886 \mathrm{t}$ ), and Greece $(2000000 \mathrm{t}) .^{28}$ According to statistics released by the International Olive Oil Council, Turkey ranked fifth in olive oil production in the harvest year 2011/2012 after Spain, Italy, Greece, and Syria. ${ }^{29}$ Turkish olive cultivars such as Ayvalik, Memecik, Gemlik, and Nizip Yaglik are known for their oils with distinctive sensory features. ${ }^{30}$ In a limited number of studies, DNA markers were used for the molecular characterization of Turkish olive cultivars. ${ }^{31-34}$ However, there is no report on the use of molecular markers for establishing DNA barcodes of Turkish monovarietal olive oils. The aim of this work was to discriminate commonly cultivated Turkish olive varieties using the fewest possible SNP markers and to standardize SNP-based molecular assays that complement the shortcomings of conventional analytical approaches in resolving the traceability of premium monovarietal olive oils.

\section{MATERIALS AND METHODS}

Plant Material and Oil Samples. Leaf and oil samples of 17 commonly cultivated Turkish olive varieties were used in this study. Leaf samples of each olive variety were collected from three individual plants. Cultivar names and primary usage information are provided in Table 1. Leaf samples and filtered monovarietal oils produced by a laboratory-scale mill were obtained from the Olive Research Institute (Izmir, Turkey). Commercial olive oil samples were obtained from a retail market.
Table 1. Olive Varieties Used in The Study

\begin{tabular}{lll}
\multicolumn{1}{c}{ olive variety } & common usage ${ }^{a}$ & region of cultivation \\
Memecik & oil & southern Aegean \\
Gemlik (Trilye) & table/oil & Marmara \\
Ayvalik & oil & northern Aegean \\
Uslu & oil/table & southern Aegean \\
Erdek Yaglik & table/oil & Marmara \\
Kilis Yaglik & oil & southeast Anatolia \\
Nizip Yaglik & oil & southeast Anatolia \\
Tesbih Celebi & oil & southeast Anatolia \\
Tekirdag Siyah Salamura & table/oil & Marmara \\
Domat & table/oil & Aegean \\
Yun Celebi & oil/table & southeast Anatolia \\
Cekiste & table/oil & Aegean \\
Mavi & oil & southeast Anatolia \\
Sinop No:5 & oil & Black Sea \\
Patos & oil/table & Black Sea \\
Maraş No:7 & oil & southeast Anatolia \\
Saurani & oil & Mediterranean
\end{tabular}

${ }^{a}$ Primary usage is indicated first for the varieties that have both uses.

DNA Isolation. DNA from the leaf tissue of three replicate plants was isolated from $200 \mathrm{mg}$ of liquid nitrogen-frozen ground leaf tissue using a CTAB method. ${ }^{35}$ For isolating DNA from monovarietal olive oil samples, Wizard Magnetic DNA Purification System for Food (Promega Corp., Madison, WI) was used according to the manufacturer's instructions. The concentration of DNA from leaf and oil samples was measured using a Qubit 2.0 Fluorometer (Life Technologies, Thermo Fisher Scientific Inc., Waltham, MA) with dsDNA BR Assay Kit (Life Technologies). DNA integrity was checked on a $1.5 \%$ agarose gel.

Primer Design, Sequencing, and SNP Identification. Primers that amplify targets from the Cycloarthenol synthase and Lupeol synthase genes were designed on the basis of the partial coding sequences Genbank Acc. No. AY847065 and AY847066, respectively (http:// www.ncbi.nlm.nih.gov/genbank) (Table 2). The primer design process was carried out using Primer 3 software. ${ }^{36}$ The primers Cyc6-F and Lup1-F\&R were previously reported by Bazakos et al. ${ }^{21}$ (Table 2). Primers that target the Anthocyanidin synthase (Ant-F\&R), Calcium binding protein (Cbp-F\&R), and Chalcone synthase (Chs-F\&R) genes were reported by Consolandi et al. ${ }^{1}$ (Table 2).

Leaf DNA from the 17 olive varieties was used for dye-terminator sequencing reactions. Sequencing targets were amplified in $20 \mu \mathrm{L}$ reaction mixtures containing $1 \mathrm{X}$ PCR buffer, $1.5 \mathrm{mM} \mathrm{MgCl}_{2}, 0.25 \mathrm{mM}$ of each deoxyribonucleotide triphosphate (dNTP) (Promega Corp.), 1 $\mathrm{U}$ Taq polymerase, $0.25 \mu \mathrm{M}$ of each primer, and $5 \mathrm{ng}$ template DNA. Thermal cycling conditions consisted of one cycle of initial denaturation for $10 \mathrm{~min}$ at $94{ }^{\circ} \mathrm{C}$, followed by 35 cycles of $94{ }^{\circ} \mathrm{C}$ for $30 \mathrm{~s}, 57^{\circ} \mathrm{C}$ for $30 \mathrm{~s}, 72{ }^{\circ} \mathrm{C}$ for $45 \mathrm{~s}$, with a final extension step of 10 $\min$ at $72{ }^{\circ} \mathrm{C}$. For each olive variety, PCR reactions were performed in five replicates and combined during the purification step with the DNA Clean \& Concentrator-5 Kit (Zymo Research, Irvine, CA). Purified PCR products were used as template in dye-terminator sequencing reactions, prepared using GenomeLab DTCS Quick Start Kit (Beckman Coulter, Brea, CA) according to the manufacturer's instructions. Sequencing reaction thermal cycling conditions were 30 cycles of $96{ }^{\circ} \mathrm{C} 20 \mathrm{~s}, 50{ }^{\circ} \mathrm{C} 20 \mathrm{~s}, 60^{\circ} \mathrm{C} 4 \mathrm{~min}$. The reaction mixture for each amplicon was then purified using ZR DNA Sequencing Clean-up Kit (Zymo Research), resuspended in $30 \mu \mathrm{L}$ of sample loading solution (Beckman Coulter), and run on a Beckman CEQ8800 capillary electrophoresis device using the LFR-c method (injection voltage $2.0 \mathrm{kV}$ for $10-15 \mathrm{~s}$, separation temperature $60^{\circ} \mathrm{C}$, separation voltage $7.4 \mathrm{kV}$, separation time $45 \mathrm{~min}$ ). Sequence peaks were visualized by Beckman CEQ8800 software version 8.0 (Beckman Coulter), and SNP detection was done by visual inspection of sequence peaks from different varieties. 
Table 2. List of Primers Used for SNP Identification and Genotyping ${ }^{a}$

\begin{tabular}{|c|c|c|c|c|c|}
\hline primer $^{b}$ name & sequence $\left(5^{\prime}\right.$ to $\left.3^{\prime}\right)$ & product size & assay name & SNP alleles & $\operatorname{motif}^{c}\left(5^{\prime}\right.$ to $\left.3^{\prime}\right)$ \\
\hline Ant-F* & GCCCAGCAACAAGTGAGTATG & 274 bp & SNP3-HphI & $\mathrm{C} / \mathrm{T}$ & GGTGA \\
\hline Ant- $R^{*}$ & GACССАТTTTCССТСАСАGA & & & & \\
\hline$C b p-F^{*}$ & CAGGAATTCCAAGCCTTCAG & $328 \mathrm{bp}$ & SNP6-EagI & $\mathrm{C} / \mathrm{G}$ & CGGCCG \\
\hline$C b p-R^{*}$ & GCTCGACGGATGAGATCAAT & & & & \\
\hline$C h s-F^{*}$ & TCGGAGATTACTGCGGTTACTT & 297 bp & SNP2-BsgI & $\mathrm{C} / \mathrm{T}$ & CTGCAC \\
\hline Chs-R* & CTAGAGGCTGGAATGCTTCA & & & & \\
\hline Cyc1-F & TTTGCTCCCAGGTCATTA & $165 \mathrm{bp}$ & & & \\
\hline Cyc1-R & GGATGCTGTAGCATGACA & & & & \\
\hline$C y c 2-F$ & TGGTTTGCCTTTTCATTT & $168 \mathrm{bp}$ & SNP4-Hpy166II & $\mathrm{C} / \mathrm{T}$ & GTNNAC \\
\hline$C y c 2-R$ & АССАААТТСТТССССААG & & & & \\
\hline Cyc3-F & AGCTTGGGGAAGAATTTGGTC & 198 bp & & & \\
\hline Cyc3-R & ATATCGCCTGGGCAATCCTC & & & & \\
\hline Cyc4-F & TCTTTTCTTTAGGCGGTTC & $173 \mathrm{bp}$ & & & \\
\hline Cyc4-R & AGGTGGAAACATCACAATG & & & & \\
\hline Cyc5-F & AACAGCAATTGTTGGTGAA & $163 \mathrm{bp}$ & SNP5-HindIII & $\mathrm{C} / \mathrm{T}$ & AAGCTT \\
\hline Cyc5-R & ATCССТTTCCGAAAACAA & & & & \\
\hline Cyc6-F** & TTCTGTTGTTTTCGGAAAGG & $220 \mathrm{bp}$ & & & \\
\hline Cyc6-R & TGGAGCCATCTTTTTCCAAT & & & & \\
\hline Lup1-F** & GCAACTCAAATGAATGAATC & $125 \mathrm{bp}$ & & & \\
\hline Lup1-R** & TCTAAGAAACGGACTTGCTAT & & & & \\
\hline Lup2-F & AGTAGCATACCCTGTGTTTC & 204 bp & & & \\
\hline Lup2-R & TTGCTTGTTGGGTAGAAGAT & & & & \\
\hline Lup3-F & ACCCTGTGTTTCGATTTGCT & $107 \mathrm{bp}$ & SNP1-HруCH4III & $\mathrm{A} / \mathrm{T}$ & ACNGT \\
\hline Lup3-R & ATGCAGGTTATTTTCTTTCATCA & & & & \\
\hline
\end{tabular}

${ }^{a}$ Unless indicated otherwise, primers were designed in this study. ${ }^{b}$ Single asterisk indicates primers reported by Consolandi et al. (2008). Double asterisks indicate primers reported by Bazakos et al. (2012). Primers used in CAPS assays are given in italics. ${ }^{c}$ Nucleotides in bold indicate SNP loci in motifs.

Design and Application of the CAPS Assays for SNP Genotyping. Sequences obtained by the dye-terminator method were analyzed with the NEBcutter Version 2.0 software (http://tools. neb.com/NEBcutter2/) (New England Biolabs Inc., Ipswich, MA) for the allelic variants of each SNP identified. SNPs with alleles that alter recognition motifs of restriction enzymes were selected for genotyping by a restriction digestion-based analysis.

Fragments that harbor SNP loci were amplified in $20 \mu \mathrm{L}$ reaction mixtures containing 1 X PCR buffer, $1.5 \mathrm{mM} \mathrm{MgCl}_{2}, 0.25 \mathrm{mM}$ of each deoxyribonucleotide triphosphate (dNTP) (Promega Corp.), 1 U Taq polymerase, $0.25 \mu \mathrm{M}$ of each primer, and $5 \mathrm{ng}$ of olive leaf DNA or 5 ng of oil DNA stock solution as template. Thermal cycling conditions consisted of one cycle of initial denaturation for $10 \mathrm{~min}$ at $94{ }^{\circ} \mathrm{C}$, followed by 40 cycles ( 35 cycles for leaf DNA) of $94^{\circ} \mathrm{C}$ for $30 \mathrm{~s}, 57$ ${ }^{\circ} \mathrm{C}$ for $30 \mathrm{~s}, 72{ }^{\circ} \mathrm{C}$ for $45 \mathrm{~s}$, with a final extension step of $10 \mathrm{~min}$ at 72 ${ }^{\circ} \mathrm{C}$. PCR products were directly subjected to restriction digestion without any purification step. Digestion reaction mixtures of the CAPS assays (Table 2) contained $20 \mu \mathrm{L}$ of PCR product, $1 \mu \mathrm{L}$ of restriction enzyme (New England Biolabs Inc.), and $2.5 \mu \mathrm{L}$ of CutSmart reaction buffer (New England Biolabs Inc.) in a total volume of $25 \mu \mathrm{L}$. Reaction mixtures of the enzyme EagI involved NEBuffer 3.1 instead of the CutSmart buffer, and $0.25 \mu \mathrm{L}$ of $S$-adenosylmethione was added to the BsgI reaction mixtures. Incubation temperature was constant $\left(37^{\circ} \mathrm{C}\right)$ for all enzymes, and incubation time was standardized as $6 \mathrm{~h}$. Following the incubation step, digestion fragments were run on a Qiaxcel Advanced capillary electrophoresis system (Qiagen, Valencia, CA) using a Qiaxcel DNA High Resolution Kit (Qiagen). QX DNA Size Marker 25-500bp, v2.0 (Qiagen) was used as the size standard, and QX Alignment Marker $15 \mathrm{bp} / 600 \mathrm{bp}$ (Qiagen) was used for aligning the size standard fragments. The high resolution run method OM800 was applied with a sample injection time of 20 s. QIAxcel ScreenGel Software (Qiagen) was used for the visualization of the digestion profiles. The six CAPS assays developed in this work were applied on the oil DNA of each olive variety in three replicates.

Statistical Analysis. The frequency of each SNP allele was determined by calculating the proportion of the occurrence of the allele to the total number of alleles at a given SNP locus. Probability of identity for individual SNP loci and the combined, multilocus probability of identity were calculated according to Paetkau et al. ${ }^{37}$ Allelic error was calculated according to Pasqualone et al. ${ }^{38}$

\section{RESULTS}

SNP Identification by Sequencing. Five olive genes, Anthocyanidin synthase (Ant), Calcium binding protein (Cbp), Chalcone synthase (Chs), Cycloarthenol synthase (Cyc), and Lupeol synthase (Lup), were targeted for SNP identification by sequencing. Leaf genomic DNA from the 17 olive varieties (Table 1) was used as template for the dye-terminator sequencing reactions. Total lengths of the sequencing targets from Cyc, Lup, Cbp, Chs, and Ant genes were 1087 (six amplicons), 436 (three amplicons), 328 (one amplicon), 297 (one amplicon), and $274 \mathrm{bp}$ (one amplicon), respectively (Table 2). Sequencing of these 12 PCR amplicons that spanned $2422 \mathrm{bp}$ of coding sequence resulted in the identification of 17 SNPs, corresponding to a frequency of 1 SNP per $142.5 \mathrm{bp}$ of coding sequence. Among these SNPs, five, one, two, six, and three SNPs were identified in the Ant, Cbp, Chs, Cyc synthase, and Lup sequences, respectively.

Design of CAPS Assays for SNP Genotyping. In order to develop a restriction digestion-based SNP genotyping strategy, sequences obtained from the five olive genes by dyeterminator method were analyzed to identify SNPs that reside in restriction enzyme recognition motifs. In the analysis, allelic variants were taken into account for each SNP, so that restriction enzymes with allele-dependent digestion patterns could be identified. As a result, allelic variants of 12 of the 17 SNP loci (71\%) were found to alter restriction enzyme recognition motifs. CAPS assays were designed for each SNP 
Table 3. Genotypes of the 17 Olive Varieties for the SNPs Used for Constructing the Cultivar Origin Identification Key

\begin{tabular}{|c|c|c|c|c|c|c|}
\hline olive variety & SNP1-HруCH4III & SNP2-BsgI & SNP3-HphI & SNP4-Hpy166II & SNP5-HindIII & SNP6-EagI \\
\hline Memecik & TA & $\mathrm{CC}$ & $\mathrm{CC}$ & TT & $\mathrm{CC}$ & GG \\
\hline Gemlik(Trilye) & TA & $\mathrm{CC}$ & СТ & $\mathrm{TC}$ & $\mathrm{CC}$ & GG \\
\hline Ayvalik & AA & CT & CT & $\mathrm{TC}$ & $\mathrm{CC}$ & GG \\
\hline Uslu & TT & $\mathrm{CC}$ & СT & TT & СT & GG \\
\hline Erdek Yaglik & TA & $\mathrm{CC}$ & СТ & TC & $\mathrm{CC}$ & GG \\
\hline Kilis Yaglik & TA & $\mathrm{CC}$ & $\mathrm{CC}$ & TT & СТ & GC \\
\hline Nizip Yaglik & AA & СТ & $\mathrm{CC}$ & TT & $\mathrm{CC}$ & GG \\
\hline Tesbih Celebi & TA & $\mathrm{CC}$ & $\mathrm{CC}$ & TT & CT & GC \\
\hline Tekirdag $S^{a}{ }^{a}$ & TA & $\mathrm{CC}$ & $\mathrm{CT}$ & $\mathrm{TC}$ & $\mathrm{CC}$ & GG \\
\hline Domat & TA & $\mathrm{CC}$ & СТ & TT & СТ & GG \\
\hline Yun Celebi & AA & $\mathrm{CC}$ & CT & TT & $\mathrm{CC}$ & GC \\
\hline Cekiste & AA & $\mathrm{CC}$ & $\mathrm{CC}$ & TT & $\mathrm{CC}$ & GG \\
\hline Mavi & TA & СТ & СТ & TT & СТ & GC \\
\hline Sinop No:5 & TT & $\mathrm{CC}$ & $\mathrm{CC}$ & TT & CT & GC \\
\hline Patos & TA & $\mathrm{CC}$ & СТ & TC & СТ & GG \\
\hline Maraş No:7 & TA & $\mathrm{CC}$ & $\mathrm{CC}$ & TT & СТ & GG \\
\hline Saurani & AA & CT & CT & TT & $\mathrm{CC}$ & GG \\
\hline
\end{tabular}

${ }^{a}$ Variety name Tekirdag Siyah Salamura is abbreviated as Tekirdag SS.

and applied on leaf DNA from three replicate plants for SNP verification (data not shown). The assays involved amplification of the PCR product that harbored the SNP, restriction digestion of the amplicon with the appropriate restriction enzyme, and visualization of the digestion pattern with capillary electrophoresis. Out of the 12 CAPS assays, a subset of six was sufficient to provide the discrimination power to distinguish 17 olive varieties. As a result, those six assays (Table 2) were used to establish an identification key for the monovarietal olive oils.

SNP1, identified in the Lup gene, had A and T variants. On the basis of SNP1 alleles, the olive varieties were separated into three groups (Table 3). A total of 5 varieties were homozygous for the A allele, 10 varieties were heterozygous carrying both $\mathrm{A}$ and $\mathrm{T}$ alleles, and 2 varieties were homozygous for the $\mathrm{T}$ allele. The $\mathrm{T}$ allele of SNP1 resulted in an intact $\mathrm{HpyCH} 4 \mathrm{III}$ recognition motif, while the A allele disrupted the motif. As a result, genotypes homozygous for the $T$ allele were distinguished by a homozygous digestion pattern with two restriction fragments, whereas genotypes homozygous for the A allele produced a single undigested fragment. Heterozygous genotypes yielded a three fragment digestion pattern with two digestion fragments and the undigested amplicon (Figures 2-4). SNP2, identified in the Chs sequence, separated the olive varieties into two groups. While 13 homozygous genotypes carried only the $\mathrm{C}$ allele, the remaining four genotypes were heterozygous and carried $\mathrm{C}$ and $\mathrm{T}$ alleles (Table 3 ). The $\mathrm{C}$ allele disrupted the recognition site for the restriction enzyme BsgI, leading to a single undigested fragment for homozygous genotypes. In contrast, heterozygous genotypes carried one copy of the intact BsgI restriction site and were distinguished by a three fragment digestion pattern in the capillary electropherograms (Figures 2-4). SNP3 was identified in the Ant sequence and allowed separation of olive varieties into two groups. Genotypes homozygous for SNP3 (seven varieties) carried only the $\mathrm{C}$ allele (Table 3 ) and were distinguished by a single undigested fragment. Whereas, due to the presence of the $\mathrm{T}$ allele, heterozygous genotypes (ten varieties) (Table 3 ) carried one copy of an intact $\mathrm{HphI}$ recognition motif and produced a three fragment $\mathrm{HphI}$ digestion pattern (Figures 2-5). SNP4 and SNP5 were both identified in sequences from the $C y c$ gene. Olive genotypes were either homozygous (TT)
(12 varieties) or heterozygous (TC) (5 varieties) for the SNP4 locus (Table 3). Homozygous genotypes were distinguished by a homozygous Hpy166II digestion pattern with two restriction fragments. Because the $C$ allele disrupted the recognition motif for the enzyme, heterozygous genotypes were identified by three fragments in their capillary electropherograms (Figures 3 and 4). SNP5 separated olive varieties into two groups of nine homozygous (CC) and eight heterozygous (TC) genotypes (Table 3). Homozygous genotypes (CC) displayed a homozygous digestion pattern with two HindIII digestion fragments in their capillary electropherograms. Heterozygous genotypes (TC) were distinguished by a three fragment digestion pattern including the two digestion fragments and the undigested amplicon (Figures 3 and 4). Olive varieties were either homozygous (GG) (12 varieties) or heterozygous (CG) (five varieties) for SNP6, identified in the Cbp gene (Table 3). Because the $G$ allele disrupted the EagI recognition motif, homozygous genotypes displayed a single undigested fragment in their capillary electropherograms. Heterozygous genotypes carrying one copy of an intact EagI recognition site were characterized by a three fragment restriction pattern (Figure 4). Allelic frequencies of the six SNP loci used for the discrimination of the olive varieties are given in Table 4 .

Fingerprinting Monovarietal Olive Oils Using SNPBased CAPS Markers. Among the six SNPs used to design CAPS assays, combinations that involved two, three, four, or five SNPs were sufficient to discriminate the olive varieties (Figure 1). Therefore, variable sets of CAPS assays were applied to the oil DNA samples of the 17 varieties. SNP1$\mathrm{HpyCH} 4 \mathrm{III}$ assay was common in the discriminatory assay combinations for all varieties. However, different combinations of the remaining five assays (SNP2-BsgI, SNP3-HphI, SNP4Hpy166II, SNP5-HindIII, and SNP6-EagI) were used for the identification of the olive varieties.

Only two SNPs were sufficient to discriminate Uslu, Mavi, and Sinop No:5 varieties. Discrimination of both Uslu and Sinop No:5 oils involved using the SNP1-HpyCH4III and SNP3-HphI assay combination (Figure 2). The SNP2-BsgI assay was used instead of SNP3-HphI for the discrimination of the Mavi variety (Figure 2). Identification of the varieties, Nizip Yaglik, Yun Celebi, and Cekiste, involved using three SNPs. A 
Table 4. Allele Frequency, Informativeness, and Reproducibility of the Six SNP Markers, Expressed as Probability of Identity and Allelic Error, Respectively

\begin{tabular}{|c|c|c|c|c|}
\hline \multirow[t]{2}{*}{ SNP locus } & \multicolumn{2}{|c|}{$\mathrm{AF}^{a}$} & \multirow[t]{2}{*}{$\mathrm{PI}^{b}$} & \multirow[t]{2}{*}{$\mathrm{AE}^{c}$} \\
\hline & $\mathrm{T}$ & A & & \\
\hline \multirow[t]{2}{*}{ SNP1 } & 0.41 & 0.59 & 0.383 & 0.000 \\
\hline & $\mathrm{C}$ & $\mathrm{T}$ & & \\
\hline \multirow[t]{2}{*}{ SNP2 } & 0.88 & 0.12 & 0.649 & 0.000 \\
\hline & $\mathrm{C}$ & $\mathrm{T}$ & & \\
\hline \multirow[t]{2}{*}{ SNP3 } & 0.71 & 0.29 & 0.428 & 0.000 \\
\hline & $\mathrm{C}$ & $\mathrm{T}$ & & \\
\hline \multirow[t]{2}{*}{ SNP4 } & 0.15 & 0.85 & 0.593 & 0.000 \\
\hline & $\mathrm{C}$ & $\mathrm{T}$ & & \\
\hline \multirow[t]{2}{*}{ SNP5 } & 0.76 & 0.24 & 0.475 & 0.000 \\
\hline & G & $\mathrm{C}$ & & \\
\hline SNP6 & 0.85 & 0.15 & 0.593 & 0.000 \\
\hline multilocus PI & & & 0.018 & \\
\hline
\end{tabular}

common set of CAPS assays (SNP1-HpyCH4III, SNP2-BsgI, and SNP3-HphI) was used to discriminate the monovarietal oils of these varieties (Figure 2). The varieties Memecik, Ayvalik, Domat, and Saurani could be discriminated from the rest using four SNPs. Ayvalik, Domat, and Saurani oils were discriminated using an identical set of assays that included
SNP1-HpyCH4III, SNP2-BsgI, SNP3-HphI, and SNP4Hpy166II (Figure 3) whereas the SNP5-HindIII assay was required instead of SNP4-Hpy166II for the discrimination of Memecik oil (Figure 3). Among the 17 commonly cultivated Turkish olive varieties included in this work, two groups of cultivars were suggested as synonyms by the experts of the Olive Research Institute (Izmir, Turkey) based on long-term agromorphological observations. In agreement with these observations, the genotypes of the two groups of varieties were identical for all of the 17 SNPs identified in this study (data not shown). However, further detailed molecular genetic characterization would confirm whether the two groups of olive varieties are actually synonyms. The first group of varieties that are suggested as synonyms was Gemlik, Erdek, and Tekirdag Siyah Salamura. A combination of five CAPS assays (SNP1HpyCH4III, SNP2-BsgI, SNP3-HphI, SNP4-Hpy166II, and SNP5-HindIII) allowed the discrimination of these three monovarietal oils from the rest of the collection (Figure 4). The second group of varieties suggested as synonyms was Kilis Yaglik and Tesbih Celebi. By using a set of five CAPS assays (SNP1-HpyCH4III, SNP2-BsgI, SNP3-HphI, SNP5-HindIII, and SNP6-EagI), the oils of these two varieties were discriminated from the rest of the monovarietal olive oils (Figure 4). Olive varieties Patos and Maras No:7 were also distinguished from the rest using five SNPs. Thus, a set of five assays (SNP1-HpyCH4III, SNP2-BsgI, SNP3-HphI, SNP4-

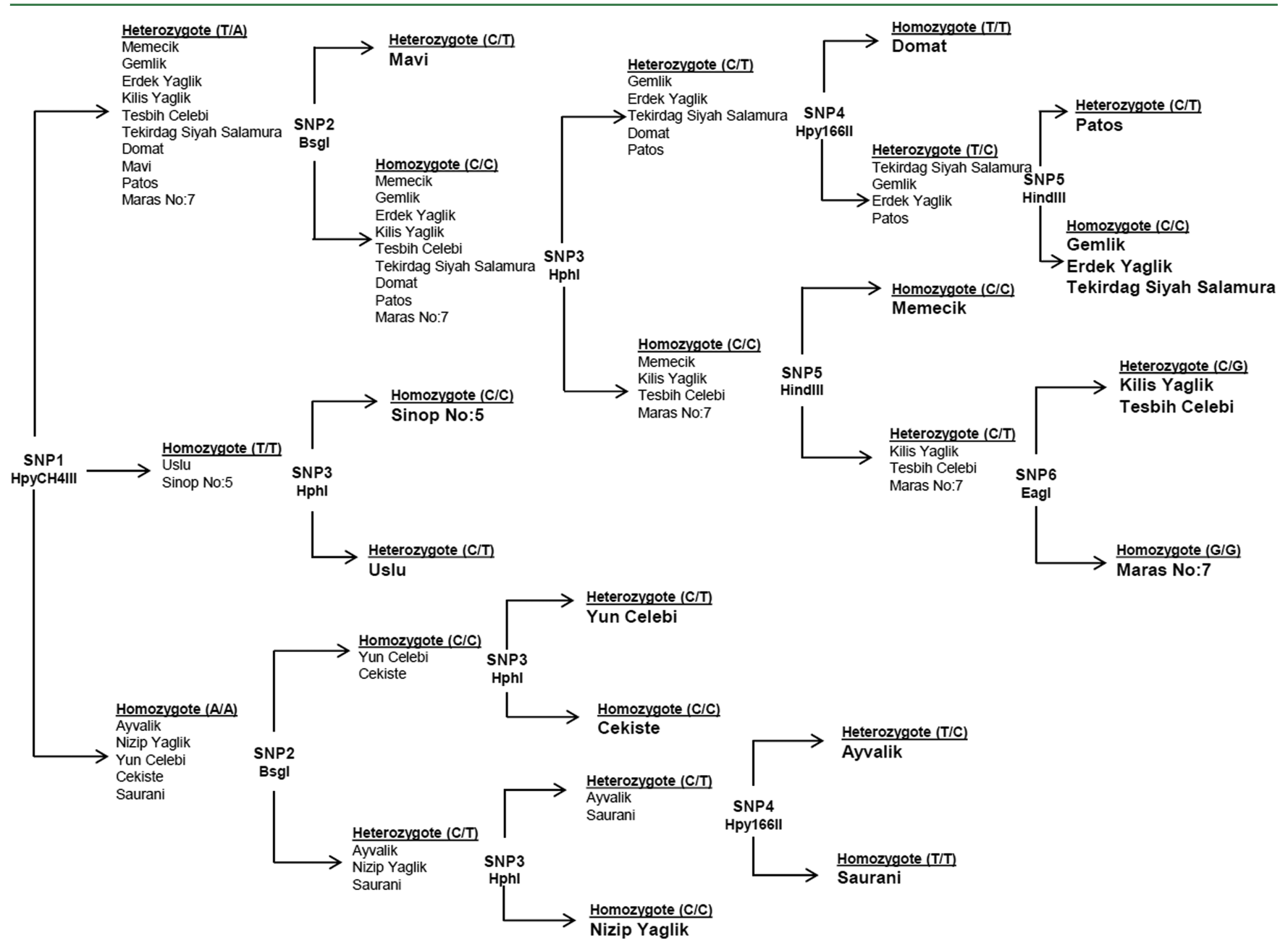

Figure 1. Identification key displaying the discrimination of Turkish olive cultivars according to SNP-based CAPS assays. 

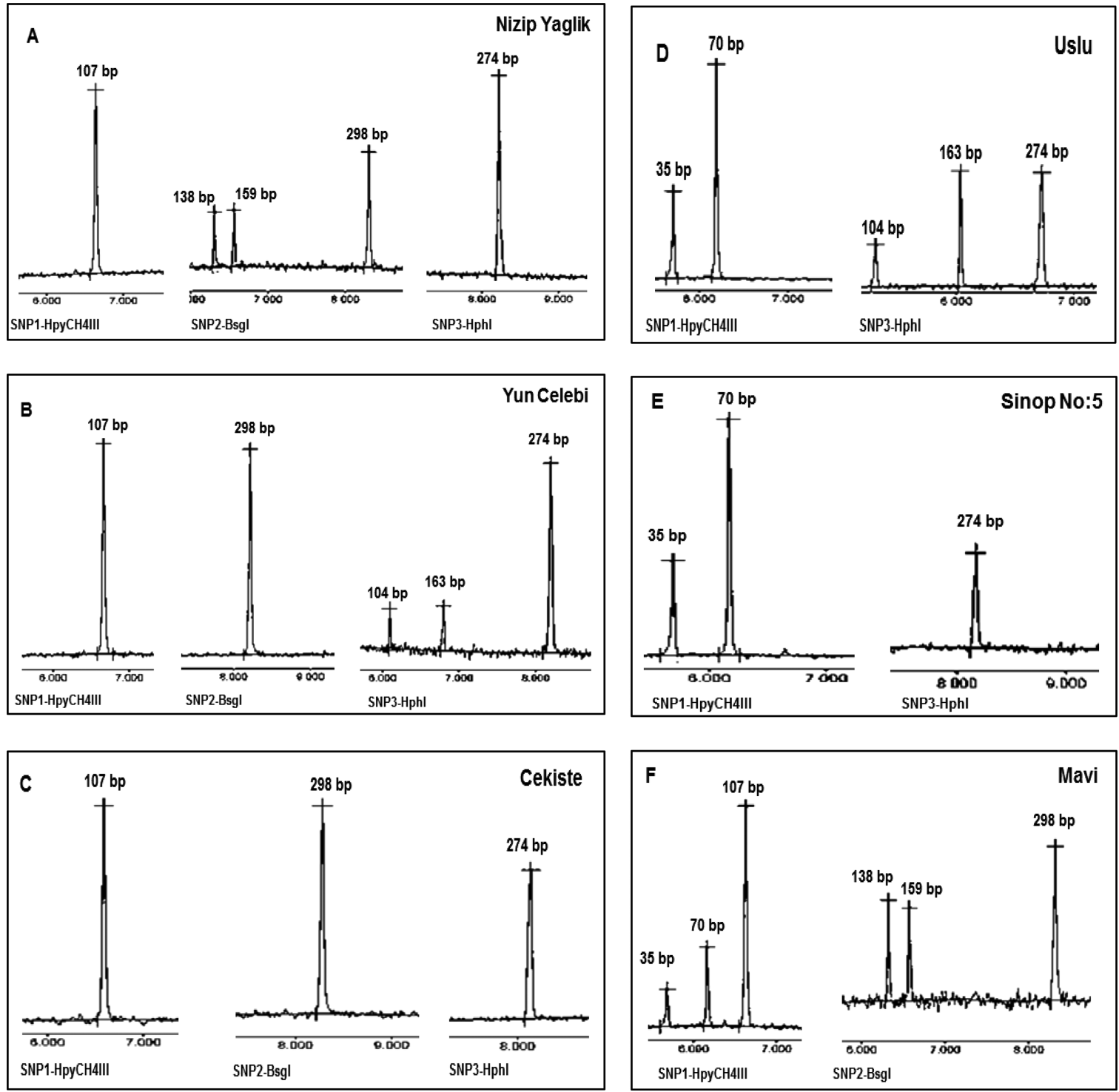

Figure 2. Electrophoretic patterns obtained by SNP-based CAPS assays for the monovarietal olive oils discriminated by two or three SNPs. Each capillary electropherogram displays the result of a SNP-based CAPS assay: A, Nizip Yaglik; B, Yun Celebi; C, Cekiste; D, Uslu; E, Sinop No:5; F, Mavi.

Hpy166II, and SNP5-HindIII) was used for the discrimination of Patos oil (Figure 4), while the SNP6-EagI assay was interchanged with the SNP4-Hpy166II assay for the discrimination of Maras No:7 oil (Figure 4).

Application of the SNP-Based CAPS Markers for Detecting Olive Oil Mixtures and Commercial Oil Samples. We tested the usefulness of our CAPS assays in identifying olive oil admixtures. For this purpose, we used oil from the Memecik and Uslu varieties, both of which are commonly cultivated in the South Aegean region of Turkey. We prepared admixtures of Memecik and Uslu oils at different ratios, extracted DNA from those admixtures, and applied the SNP3-HphI assay to determine if we could detect the contribution of DNA from the Uslu oil in the admixtures. When applied on the Memecik variety, the SNP3-HphI assay yielded a single, undigested fragment (Figure 3). Because Uslu was heterozygous for SNP3, application of the same assay yielded a three-fragment digestion pattern when applied on the oil of this variety (Figure 2). Therefore, any digestion fragment alongside the undigested band would be proof of an impurity in a Memecik oil sample. The olive oil samples prepared for the admixture detection assay contained 50\%, 40\%, 30\%, 20\%, and $10 \%$ of Uslu oil added to Memecik oil. In order to assess the limit of detecting olive oil admixtures confidently, SNP3-HphI assay was carried out in three replicates on each DNA sample. As a result of the analysis, we successfully detected Uslu oil contribution down to a limit of $20 \%$ (Figure 5). Because the admixture with $10 \%$ Uslu oil was detected only once out of the three replicate analyses, a $10 \%$ contribution by an undeclared variety was considered to be below the limit of detection of the CAPS analysis (data not shown).

We further tested the applicability of the SNP-based CAPS markers on two commercial olive oil samples. While sample no. 1 had its cultivar origin declared on the label as "Memecik", sample no. 2 was not labeled as a monovarietal product. A DNA concentration of approximately $2 \mathrm{ng} / \mu \mathrm{L}$ was measured by fluorometer for both of the commercial samples, which constituted a sufficient quantity of template DNA for further PCR amplifications. The entire set of six CAPS assays (Table 2) was applied on DNA from both samples in three replicates. 

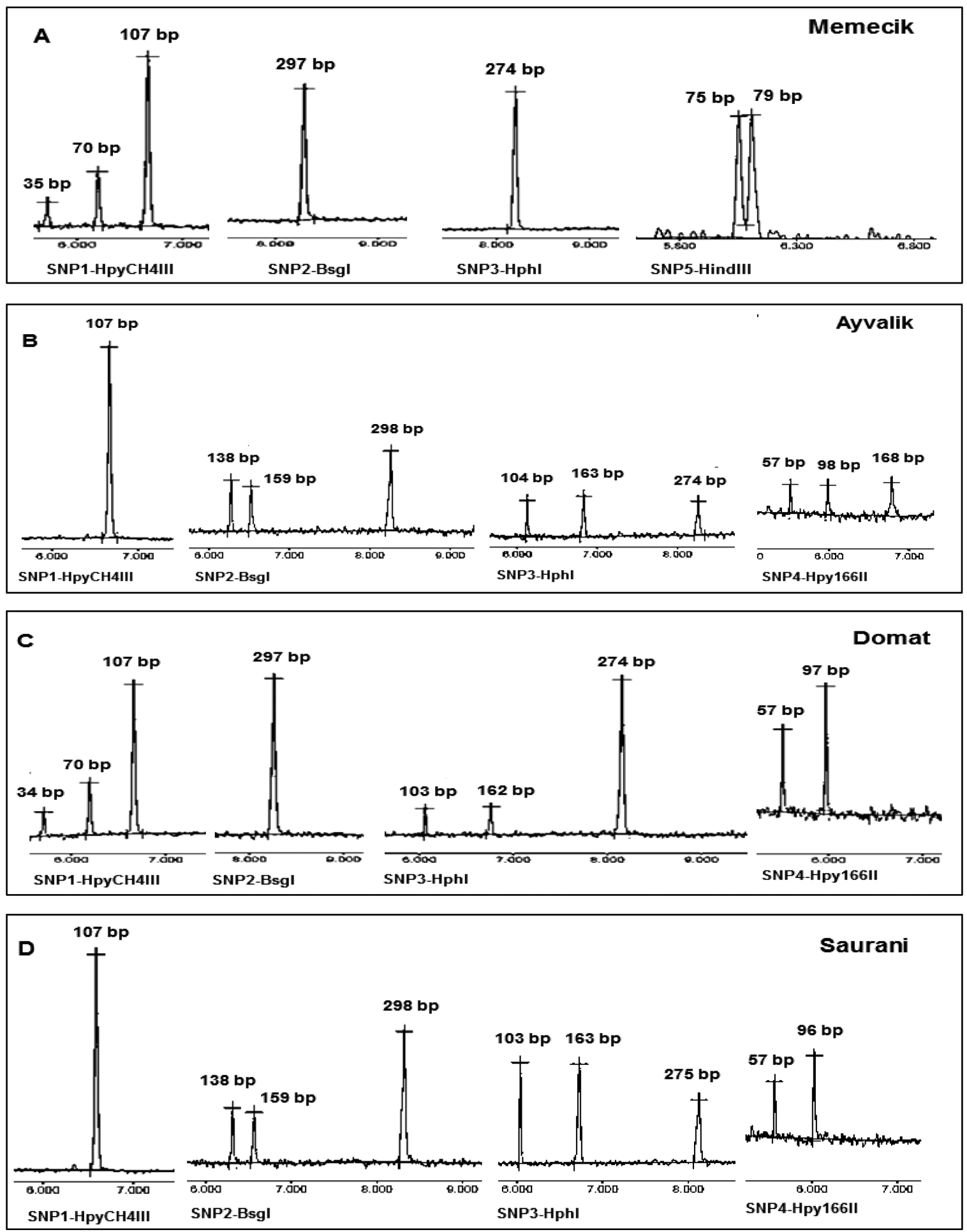

Figure 3. Electrophoretic patterns obtained by SNP-based CAPS assays for the monovarietal olive oils discriminated by four SNPs. Each capillary electropherogram displays the result of a SNP-based CAPS assay: A, Memecik; B, Ayvalik; C, Domat; D, Saurani.

For sample no. 1, the digestion profiles resulting from the six assays (Figure 6) were in agreement with the genotype of the Memecik variety (Table 2 ), and did not provide any evidence to suspect the declared varietal origin of the product. In case of sample no. 2, the digestion profiles obtained from the six assays (Figure 7) matched the combined SNP genotypes of none of the 17 varieties (Table 2). In addition, the result of the SNP2BsgI assay (Figure 7) excluded the four varieties, Ayvalik, Nizip Yaglik, Mavi, and Saurani, as these varieties were heterozygous for this locus. As a result, it was concluded that either the cultivar origin of sample no. 2 was not represented in the set of 17 varieties or the product was a mixture of the oils from different varieties. The latter seemed to be a more viable explanation, because sample no. 2 was not declared as a monovarietal product on the label and the genotypes included in this work represent the most commonly cultivated Turkish olive varieties. 

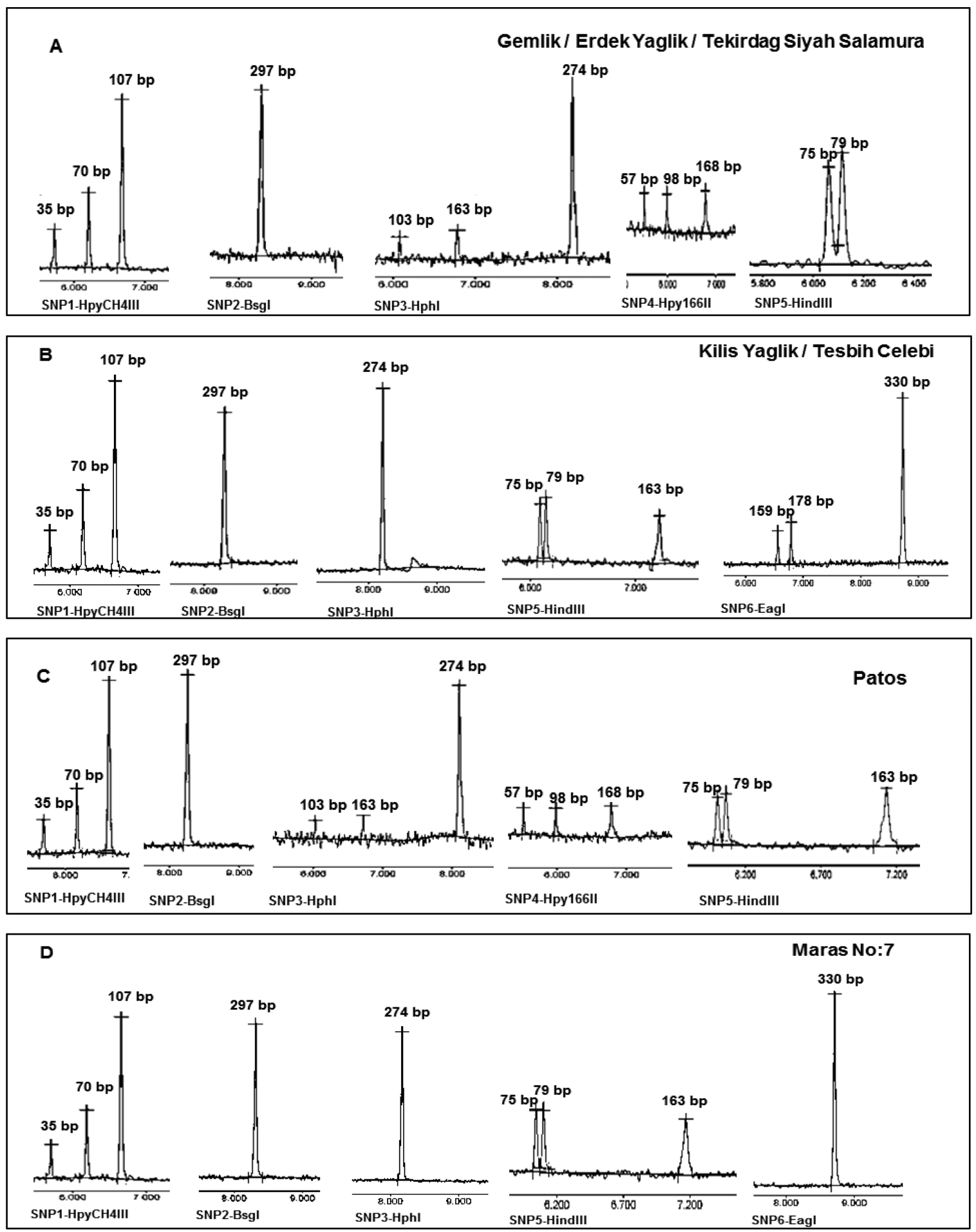

Figure 4. Electrophoretic patterns obtained by SNP-based CAPS assays for the monovarietal olive oils discriminated by five SNPs. Each capillary electropherogram displays the result of a SNP-based CAPS assay: A, Gemlik, Erdek Yaglik, Tekirdag Siyah Salamura; B, Kilis Yaglik, Tesbih Celebi; C, Patos; D, Maras No:7.

\section{DISCUSSION}

As an agro-food product with great economic value, virgin olive oil is an attractive target for adulteration and mislabeling. While olive oils with mislabeled cultivar origin do not constitute a health threat, traceability protocols to verify the authenticity of genuine products should be established to protect basic consumer rights. Several researchers reported that the chemical composition of oil extracted from the same olive variety is highly affected by climatic conditions, ${ }^{9}$ agricultural practices, ${ }^{10,11}$ time of harvest, ${ }^{12}$ extraction procedure, and packaging and storage conditions. ${ }^{13}$ In contrast, DNA-based assays are not influenced by compositional variations due to external effects. Therefore, either alone ${ }^{21}$ or in combination with analytical chemistry methods, ${ }^{2}$ DNA-based assays are increasingly used to authenticate monovarietal olive oils. The recovery of a sufficient quantity and quality of DNA is a key step in the success in 


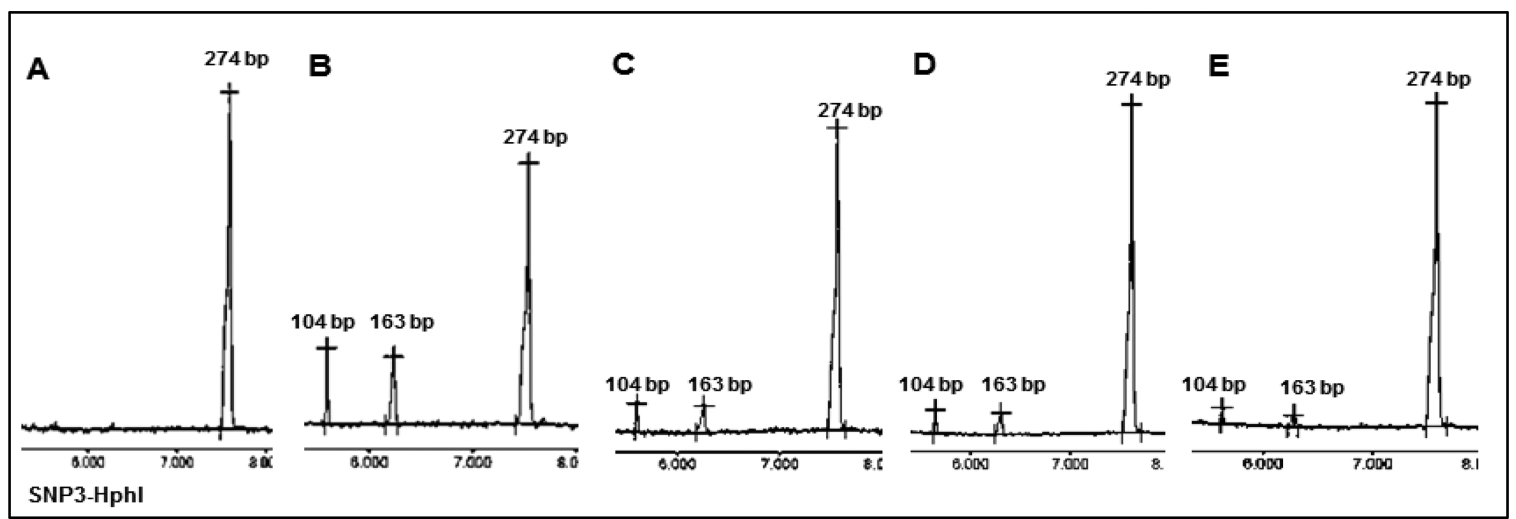

Figure 5. Capillary electropherograms displaying the results of SNP3-HphI assay applied on olive oil admixtures: A, 100\% Memecik oil; B, 50\% Memecik oil/50\% Uslu oil; C, 60\% Memecik oil/40\% Uslu oil, D, 70\% Memecik oil/30\% Uslu oil; E, 80\% Memecik oil/20\% Uslu oil.

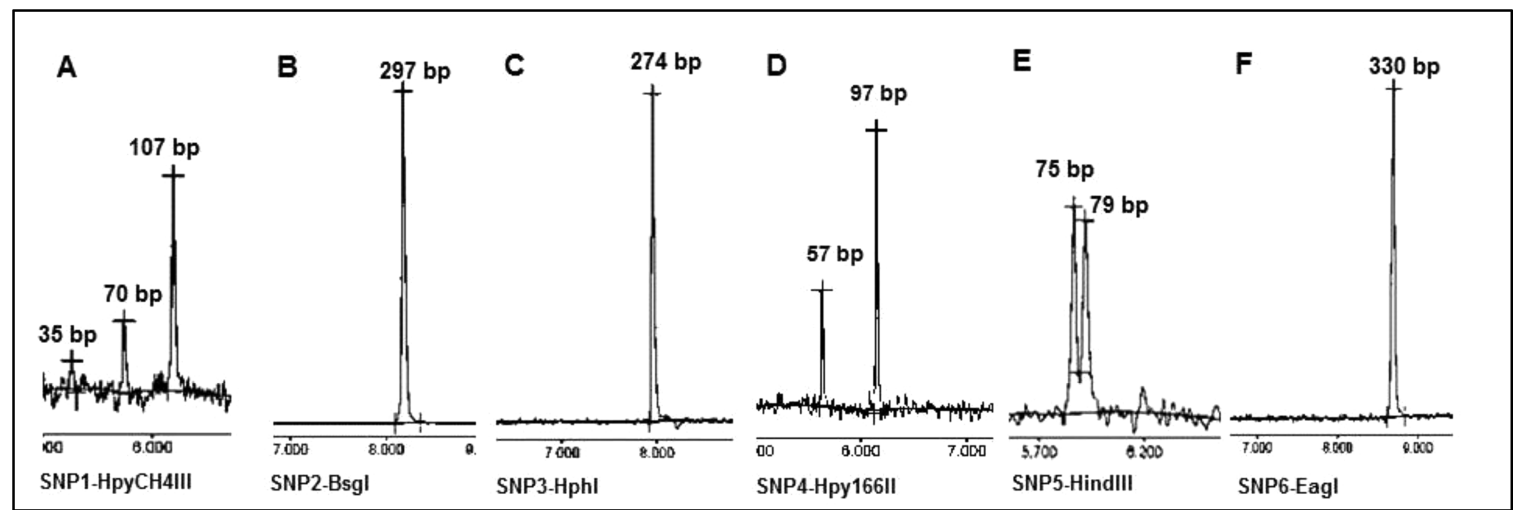

Figure 6. Capillary electropherograms displaying the results of the SNP1-HpyCH4III, SNP2-BsgI, SNP3-HphI, SNP4-Hpy166II, SNP5-HindIII, and SNP6-EagI assays applied on commercial sample no. 1.

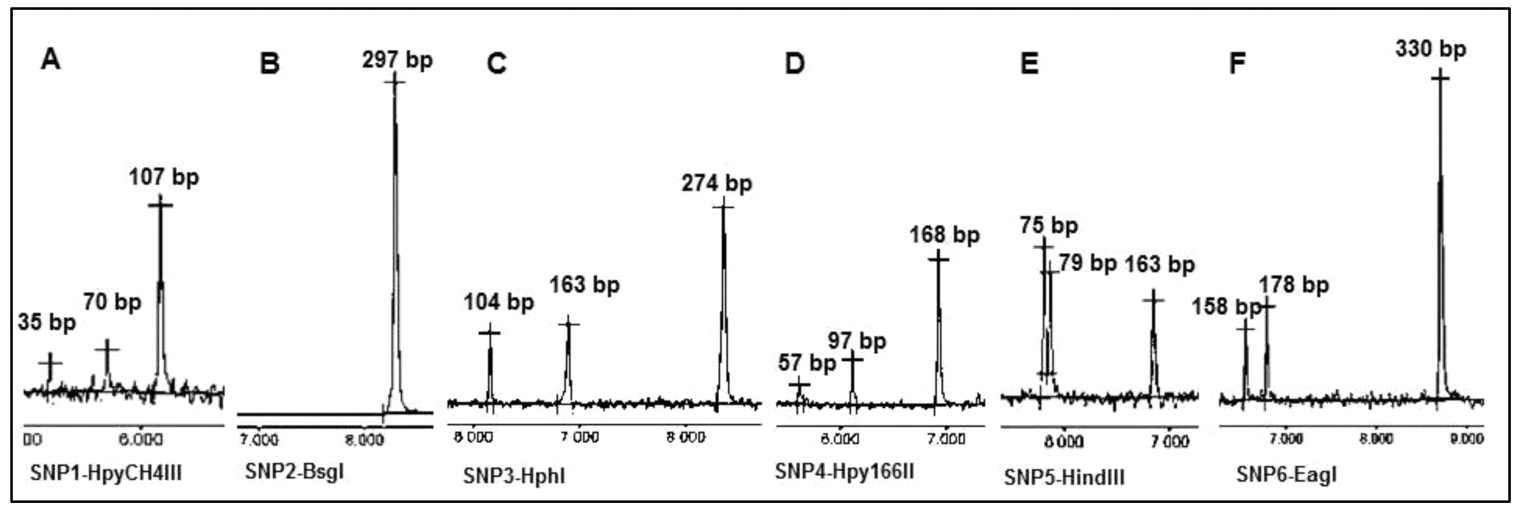

Figure 7. Capillary electropherograms displaying the results of the SNP1-HpyCH4III, SNP2-BsgI, SNP3-HphI, SNP4-Hpy166II, SNP5-HindIII, and SNP6-EagI assays applied on commercial sample no. 2.

DNA-based olive oil authentication. Different authors recommend various commercial kits or in-house protocols. ${ }^{1,16,17,39}$ When we compared different commercial kits and an in-house $\mathrm{CTAB}$ based protocol, we found that commercial kits are faster and more consistent in yielding amplifiable DNA from olive oil samples. While a DNA concentration that ranges between $100-200 \mathrm{ng} / \mu \mathrm{L}$ was obtained from olive leaf samples with the $\mathrm{CTAB}^{35}$ method, the DNA extracted using the same method from oil samples was often below the limit of detection of the fluorometer. In contrast, commercial kits were consistent in yielding a DNA concentration of $2-4 \mathrm{ng} / \mu \mathrm{L}$ from the oil samples, with no visible sign of degradation on the agarose gel.
Therefore, our experience suggests using food-specific commercial kits to ensure successful downstream applications.

We used SNP markers in our study as their abundance in the genome makes them ideal for identifying differences between closely related genotypes. ${ }^{6}$ The SNP frequency we identified in olive coding sequences (1 SNP per $142.5 \mathrm{bp}$ ) was similar to the results of Reale et al., ${ }^{24}$ who reported a frequency of 1 SNP per $156 \mathrm{bp}$ in the Cycloarthenol synthase, Lupeol synthase, and $\mathrm{Cu}-$ $\mathrm{Zn}$-superoxide dismutase genic sequences. The high frequency of single nucleotide polymorphisms identified in olive coding sequences suggests that olive germplasm harbors a high level of genotypic diversity. Indeed, Belaj et al. ${ }^{40}$ reported high genetic 
diversity in both local olive germplasm and collections of cultivars representing different cultivation regions. Despite clonal propagation, a high genetic variability is not unexpected in olive because Olea europaea L. is an outcrossing species and interfertile with oleasters (wild olives). ${ }^{40,41}$ Among the six SNPs used in the identification key, three were reported in previous work. SNP2, identified in the Chalcone synthase gene, was reported by Consolandi et al. ${ }^{25}$ SNP5, identified in the Cycloarthenol synthase gene, was also reported by Consolandi et al., ${ }^{25}$ and Bazakos et al. ${ }^{21}$ In addition, we found that the SNP in the Calcium binding protein gene, first described by Reale et al., $^{24}$ was also polymorphic in Turkish germplasm and is referred to as SNP6 in this study. These results demonstrate that SNPs in olive coding sequences are conserved across the geography of olive distribution and can be useful for estimating ancestral alleles via phylogenetic analysis.

Restriction digestion-based SNP genotyping is a highly reproducible strategy, producing results that are not prone to variable interpretation in different hands. Very high reproducibility is due to the fact that genotyping is based on observing digestion patterns and does not involve any fluorescence signal intensity measurements or fragment size comparisons. In addition, there is no requirement for SNP-specific probe design or sophisticated equipment. ${ }^{42}$ Regular PCR primers are sufficient for the application of SNP-based CAPS assays. Restriction enzymes recognizing a wide variety of sequence motifs are available, making restriction digestion-based SNP genotyping a highly feasible strategy. In this work, a high proportion $(70 \%)$ of the identified SNPs were amenable to genotyping by CAPS strategy, and only six CAPS assays were sufficient to reach our aim of establishing an identification key for 17 monovarietal olive oils. According to long-term observation of agromorphological traits, two groups of varieties included in this work were suggested as synonyms by the experts of the Olive Research Institute (Izmir, Turkey). The first group of putative synonyms consisted of Gemlik, Erdek Yaglik, and Tekirdag Siyah Salamura, while the second group included Kilis Yaglik and Tesbih Celebi (personal communication). These varieties were included in our analysis in order to investigate if the DNA-based assay produced false positive results by identifying clones as distinct varieties. As a result, we found that the putative synonyms carried identical alleles for the 17 SNP loci identified in five genes, and they were grouped as indistinguishable varieties in the identification key (Figure 1). This result can be attributed to the fact that the SNP loci identified in this work reside in coding sequences. However, performing a detailed molecular genetic characterization involving markers from both coding and noncoding regions may result in distinguishing the putatively synonymous varieties.

When we applied SNP-based CAPS assays on monovarietal olive oils, we were able to obtain the expected digestion profiles. Indeed, SNP-based CAPS analysis proved highly reproducible, and produced identical banding patterns in all three replicate experiments. As a result, the allelic error was found to be 0.000 for the six SNP-based CAPS markers (Table 4). As expected for SNP markers due to their biallelic nature, ${ }^{23}$ the multilocus probability of identity value of the SNP loci was moderately low (0.018). By following the identification key (Figure 1) introduced in this work, the cultivar origins of oils from the 17 Turkish olive varieties can be identified and authenticated. Given that the genotypes included in this work represent the most commonly cultivated olive varieties in
Turkey, we expect that the variety-specific assay combinations would largely meet the expectations of the Turkish olive oil industry for authenticating high-economic value, premium monovarietal olive oils.

The ultimate goal of cultivar origin detection analyses is to determine if the origin of an oil sample is true to its labeling. Therefore, such an assay should enable the detection of undeclared impurities in a sample. Due to the fact that both the adulterant and the adulterated food commodity are extremely similar materials, the detection of mislabeled cultivar origin is a challenging task, making it attractive for unscrupulous manufacturers or vendors to gain profit from such fraudulent practice. ${ }^{6,8}$ In addition, it is reasonable to expect that fruits of varieties cultivated in the same region are commonly processed together for oil extraction, leading to unintended mislabeling of cultivar origin. Thus, in addition to establishing a cultivar origin identification key, it was important for us to test the ability of our SNP-based CAPS assays to detect olive oil admixtures. The Memecik and Uslu varieties were specifically chosen for this kind of analysis as the oil of the Memecik variety is well-known for its sensory qualities and its area of cultivation (South Aegean region of Turkey) overlaps with that of Uslu. Therefore, we can expect that fruits of these two varieties are commonly used together for oil production. On the basis of our analysis, we could successfully detect a minimum of $20 \%$ Uslu oil mixed with Memecik oil (Figure 5). We consider this to be a good threshold of detection because, due to economic concerns, fraud generally involves much higher proportions of adulterants. However, it must be remembered that our method does not allow quantification of admixtures and that the use of different percent admixtures was solely to determine the threshold of detection.

To our knowledge, this is the first report that describes the utilization of SNP-based CAPS assays for the detection of admixtures of oils from different olive varieties. Moreover, this is the first time that SNP markers were applied on Turkish olive oils for establishing a varietal identification key and detecting olive oil admixtures. The applicability of the CAPS assays on commercial olive oil samples was also demonstrated. In addition to their use for addressing the authenticity issues of monovarietal olive oils, the CAPS assays introduced in this work will find several uses including olive tree certification, germplasm characterization, and preservation studies.

\section{AUTHOR INFORMATION}

\section{Corresponding Author}

*E-mail: samidoganlar@iyte.edu.tr. Phone: +902327507313.

\section{Funding}

This study was supported by Grant 1334 STZ 2012/1 from Republic of Turkey, Ministry of Science, Industry and Technology, with the contributions of Özaltın Agricultural Enterprises Industry and Commerce Inc., and Genmar Diagnostic Company. We are grateful to the Olive Research Institute (Izmir, Turkey) for providing oil and leaf samples.

\section{Notes}

The authors declare no competing financial interest.

\section{REFERENCES}

(1) Consolandi, C.; Palmieri, L.; Severgnini, M.; Maestri, E.; Marmiroli, N.; Agrimonti, C.; Baldoni, L.; Donini, P.; De Bellis, G.; Castiglioni, B. A procedure for olive oil traceability and authenticity: DNA extraction, multiplex PCR and LDR-universal array analysis. Eur. Food Res. Technol. 2008, 227, 1429-1438. 
(2) Pasqualone, A.; Di Rienzo, V.; Blanco, A.; Summo, C.; Caponio, F.; Montemurro, C. Characterization of virgin olive oil from Leucocarpa cultivar by chemical and DNA analysis. Food Res. Int. 2012, 47, 188-193.

(3) Agrimonti, C.; Vietina, M.; Pafundo, S.; Marmiroli, N. The use of food genomics to ensure the traceability of olive oil. Trends Food Sci. Technol. 2011, 22, 237-244.

(4) Owen, R. W.; Giacosa, A.; Hull, W. E.; Haubner, R.; Würtele, G.; Spiegelhalder, B.; Bartach, H. Olive-oil consumption and health: the possible role of antioxidants. Lancet Oncol. 2000, 1, 107-112.

(5) Perez-Jimenez, M.; Besnard, G.; Dorado, G.; Hernandez, P. Varietal tracing of virgin olive oil based on plastid DNA variation profiling. PLoS One 2013, 8, e70507.

(6) Costa, J.; Mafra, I.; Oliveira, M. B. P. P. Advances in vegetable oil authentication by DNA-based markers. Trends Food Sci. Technol. 2012, $26,43-55$

(7) Woolfe, M.; Primrose, S. Food forensics: using DNA technology to combat misdescription and fraud. Trends Biotechnol. 2004, 5, 222226.

(8) Ulberth, F.; Buchgraber, M. Authenticity of fats and oils. Eur. J. Lipid Sci. Technol. 2000, 102, 687-694.

(9) Aguilera, M. P.; Beltrán, G.; Ortego, D.; Fernández, A.; Jiménez, A.; Uceda, M. Characterisation of virgin olive oil of Italian olive cultivars: 'Frantoio' and 'Leccino', grown in Andalusia. Food Chem. 2005, 89, 387-391.

(10) Gómez-Rico, A.; Salvador, M. D.; Moriana, A.; Pérez, D.; Olmedilla, N.; Ribas, F.; Freagapane, G. Influence of different irrigation strategies in a traditional Cornicabra cv. olive orchard on virgin olive oil composition and quality. Food Chem. 2007, 100, 568578.

(11) Erel, R.; Kerem, Z.; Ben-Gal, A.; Dag, A.; Schwartz, A.; Zipori, I.; Basheer, L.; Yermiyahu, U. Olive (Olea europaea L.) tree nitrogen status is a key factor for olive oil quality. J. Agric. Food Chem. 2013, 61, 11261-11272.

(12) Dag, A.; Kerem, Z.; Yogev, N.; Zipori, I.; Lavee, S.; Ben-David, E. Influence of time of harvest and maturity index on olive oil yield and quality. Sci. Hortic. 2011, 127, 358-366.

(13) Ben-Hassine, K.; Taamalii, A.; Ferchichi, S.; Mlaouah, A.; Benincasa, C.; Romano, E.; Flamini, G.; Lazzez, A.; Grati-kamoun, N.; Perri, E.; Malouche, D.; Hammami, M. Physicochemical and sensory characteristics of virgin olive oils in relation to cultivar, extraction system and storage conditions. Food Res. Int. 2013, 54, 1915-1925.

(14) Madesis, P.; Ganopoulos, I.; Bosmali, I.; Tsaftaris, A. Barcode high resolution melting analysis for forensic uses in nuts: A case study on allergenic hazelnuts (Corylus avellana). Food Res. Int. 2013, 50, $351-360$.

(15) Ganopoulos, I.; Bazakos, C.; Madesis, P.; Kalaitzis, P.; Tsaftaris, A. Barcode DNA high-resolution melting (Bar-HRM) analysis as a novel close-tubed and accurate tool for olive oil forensic use. J. Sci. Food. Agric. 2013, 93, 2281-2286.

(16) Breton, C.; Claux, D.; Metton, I.; Skorski, G.; Bervillé, A. Comparative study of methods for DNA preparation from olive oil samples to identify cultivar SSR alleles in commercial oil samples: Possible forensic applications. J. Agric. Food Chem. 2004, 52, 531-537.

(17) Testolin, R.; Lain, O. DNA extraction from olive oil and PCR amplification of microsatellite markers. J. Food Sci. 2005, 70, c108c112.

(18) Pasqualone, A.; Montemurro, C.; Summo, C.; Sabetta, W.; Caponio, F.; Blanco, A. Effectiveness of microsatellite DNA markers in checking the identity of protected designation of origin extra virgin olive oil. J. Agric. Food Chem. 2007, 55, 3857-3862.

(19) Martins-Lopes, P.; Gomes, S.; Santos, E.; Guedes-Pinto, H. DNA markers for Portuguese olive oil fingerprinting. J. Agric. Food Chem. 2008, 56, 11786-11791.

(20) Raieta, K.; Muccillo, L.; Colantuoni, V. A novel reliable method of DNA extraction from olive oil suitable for molecular traceability. Food Chem. 2014, 172, 596-602.

(21) Bazakos, C.; Dulger, A. O.; Uncu, A. T.; Spaniolas, S.; Spano, T.; Kalaitzis, P. A SNP-based PCR-RFLP capillary electrophoresis analysis for the identification of the varietal origin of olive oils. Food Chem. 2012, 134, 2411-2418.

(22) Khlestkina, E. K.; Salina, E. A. SNP markers: Methods of analysis, ways of development, and comparison on an example of common wheat. Russ. J. Genet. 2006, 42, 585-594.

(23) Ganopoulos, I.; Tsaballa, A.; Xanthopoulou, A.; Madesis, P.; Tsaftaris, A. Sweet cherry cultivar identification by high-resolutionmelting (HRM) analysis using gene-based SNP markers. Plant Mol. Biol. Rep. 2013, 31, 763-768.

(24) Reale, S.; Doveri, S.; Díaz, A.; Angiolillo, A.; Lucentini, L.; Pilla, F.; Martín, A.; Donini, P.; Lee, D. SNP-based markers for discriminating olive (Olea europaea L.) cultivars. Genome 2006, 49, $1193-1205$.

(25) Consolandi, C.; Palmieri, L.; Doveri, S.; Maestri, E.; Marmiroli, N.; Reale, S.; Lee, D.; Baldoni, L.; Tosti, N.; Severgnini, M.; De Bellis, G.; Castiglioni, B. Olive variety identification by ligation detection reaction in a universal array format. J. Biotechnol. 2007, 129, 565-574.

(26) Dooley, J. J.; Sage, H. D.; Clarke, M-A. L.; Brown, H. M.; Garrett, S. D. Fish species identification using PCR-RFLP analysis and lab-on-a-chip capillary electrophoresis: Application to detect white fish species in food products and an interlaboratory study. J. Agric. Food Chem. 2005, 53, 3348-3357.

(27) Spaniolas, S.; May, S. T.; Bennett, M. J.; Tucker, G. A. Authentication of coffee by means of PCR-RFLP analysis and lab-on-achip capillary electrophoresis. J. Agric. Food Chem. 2006, 54, 74667470.

(28) FAOSTAT. Production Statistics 2013. URL http://faostat.fao. org/site/567/DesktopDefault.aspx?PageID=567\#ancor (date accessed October 10, 2014).

(29) IOC. World Olive Oil Figures. URL http://www. internationaloliveoil.org/estaticos/view/131-world-olive-oil-figures (date accessed October 10, 2014).

(30) Ocakoglu, D.; Tokatli, F.; Ozen, B.; Korel, F. Distribution of simple phenols, phenolic acids and flavonoids in Turkish monovarietal extra virgin olive oils for two harvest years. Food Chem. 2009, 113, 401-410.

(31) Ercisli, S.; Barut, E.; Ipek, A. Molecular characterization of olive cultivars using amplified fragment length polymorphism markers. GMR, Genet. Mol. Res. 2009, 8, 414-419.

(32) Isik, N.; Doganlar, S.; Frary, A. Genetic diversity of Turkish olive varieties assessed by simple sequence repeat and sequence-related amplified polymorphism markers. Crop Sci. 2011, 51, 1646-1654.

(33) Ipek, A.; Barut, E.; Gulen, H.; Ipek, M. Assessment of inter- and intracultivar variations in olive using SSR markers. Sci. Agric. 2012, 69, 327-335.

(34) Kaya, H. B.; Cetin, O.; Kaya, H.; Sahin, M.; Sefer, F.; Kahraman, A.; Tanyolac, B. SNP discovery by Illumina-based transcriptome sequencing of the olive and genetic characterization of Turkish olive genotypes revealed by AFLP, SSR and SNP markers. PLoS One 2013, 8 , e73674.

(35) Doyle, J. J.; Doyle, J. E. Isolation of plant DNA from fresh tissue. Focus 1990, 12, 13-15.

(36) Rozen, S.; Skaletsky, H. Primer3 on the WWW for general users and for biologist programmers. In Methods in Molecular Biology: Bioinformatics Methods and Protocols, Krawetz, S., Misener, S., Eds.; Humana Press: Totowa, NJ, 2000; Vol. 132, pp 365-386.

(37) Paetkau, D.; Calwert, W.; Stirling, I.; Strobeck, C. Microsatellite analysis of population structure in Canadian polar bears. Mol. Ecol. 1995, 4, 347-354.

(38) Pasqualone, A.; Di Rienzo, V.; Nasti, R.; Blanco, A.; Gomes, T.; Montemurro, C. Traceability of Italian protected designation of origin (PDO) table olives by means of microsatellite molecular markers. J. Agric. Food Chem. 2013, 61, 3068-3073.

(39) Busconi, M.; Foroni, C.; Corradi, M.; Bongiorni, C.; Cattapan, F.; Fogher, C. DNA extraction from olive oil and its use in the identification of the production cultivar. Food Chem. 2003, 83, 127134.

(40) Belaj, A.; Dominguez-García, M. C.; Atienza, S. G.; Urdíroz, M. N.; De la Rosa, R.; Satovic, Z.; Martín, A.; Kilian, A.; Trujillo, I.; 
Valpuesta, V.; Del Río, C. Developing a core collection of olive (Olea europaea L.) based on molecular markers (DArTs, SSRs, SNPs) and agronomic traits. Tree Genet. Genomes 2012, 8, 365-378.

(41) Belaj, A.; Muńoz-diez, C.; Baldoni, L.; Porceddu, A.; Barranco, D.; Satovic, Z. Genetic diversity and population structure of wild olives from the north-western Mediterranean assessed by SSR markers. Ann. Bot. 2007, 100, 449-458.

(42) Spaniolas, S.; Bazakos, C.; Tucker, G. A.; Bennet, M. J. Comparison of SNP-based detection assays for food analysis: Coffee authentication. J. AOAC Int. 2014, 97, 1114-1120. 